\title{
Dora Vey Lives and Works in St. Petersburg. Russian Poetry Written by People and Algorithms
}

\author{
Jana Kostincová \\ (Hradec Králové, Czech Republic)
}

\begin{abstract}
:
The study deals with Russian electronic literature. It focuses on a project that was carried out by Pavel Arseniev and Mikhail Kurtov, two authors linked with St. Petersburg journal [Translit], who used texts written by algorithms (search engine spam) to introduce the poet-machine Dora Vey. This project enabled them to pose original questions about the transformations of authorship, the dialogue between the human and non-human principles that meet in the creative process, and the related questions about creative inspiration and imagination. The essay uses "the life and works" of Dora Vey to present leading tendencies in contemporary Russian poetic experiment, to show the connection between poetic practice and its theoretical reflection. It also positions the Dora Vey project within the broad context of Russian literary experiment connected with digital technology, juxtaposing the transmedia aesthetics developed and pursued by some authors connected with [Translit] journal with the multimodal experiment of "media poetry".
\end{abstract}

\section{Key words:}

Russian literature; electronic literature; media poetry; [Translit]; Dora Vey

1 The article was supported by GA ČR, it was written as a part of the research project Russian Transmedia Poetry as a Model of Literature in Post-digital Era, registration number 17-17823S. Př́spěvek vznikl za finanční podpory GA ČR, jako součást grantového projektu Ruská transmediální poezie jako model literatury v postdigitální době, registrační číslo projektu 17-17823S. 
When the Internet appeared in the Russian environment in the 1990s, it was welcomed by both authors and readers as a library, a place for archiving and unlimited dissemination of texts, as well as a constantly accessible literary salon-a place for free and unrestricted discussion. Roman Leibov, a philologist and professor of Russian literature in Tartu, metaphorically described the virtual space in relation to literature as a library with a reading room, a space for archiving information, an area of stability and text. In contrast, and yet in connection with text, Leibov found an area of instability and non-text, which he metaphorically called "a smoking room" [LEJBOV 2010]. He himself initiated several literary projects on the Web during the 1990s, but later stated that he did not consider the Internet to be a phenomenon which could bring about any radical changes [LEJBOV 2010]. Much has changed since the time of the "reading room-smoking room" concept. The initial experiments in the field of collective writing and multimedia creation, which brought popularity to hypertext literary games and videopoetry in the 1990s, were replaced by poetics based on widespread social networks. The orientation towards the computer screen and virtual space was replaced with projects connecting the virtual and urban space by using digital technology to intervene in public space. At the end of the second decade of the 21st century, two distinctive lines of literary experiment emerged in Russian digital art, which at least partially meet, be it in joint artistic projects or in their theoretical reflection. One of the lines could be called "media poetry." The second line is represented by authors of St. Petersburg journal [Translit], whose creative experimentation defies the term "media poetry." However, it is possible to claim that it corresponds with the postdigital, transmedia and posthuman aesthetics.

One of the most prominent personalities of the first line, media poetry, is the artist and theorist Natalia Fedorova, who describes her oeuvre as language art rather than poetry [FEDOROVA 2018]. Natalia Fedorova is the founder and co-organizer of the Festival of Mediapoetry 101, which has been held annually since 2015 in St. Petersburg. The name of the festival refers to the binary system, which can be perceived as a universal language enabling the translation of elements of one symbolic system into another. At this festival, media poetry is presented as a combination of literary work and broadly conceived multimodal work, necessarily overlapping into the field of scientific discourse. It is no coincidence that since its first year, the festival has been associated with the date of April 12th, the day of the first human flight into space. Considering a large number of definitions and the way the term "media poetry" is used, it is apparent that this term replaces the term "digital literature" in the Russian context. For instance, Anna Tolkacheva posits that media poetry is a synthetic kind of modern art which combines poetic text and media (most often new media), and that an important aspect of identifying a piece of work is its materiality [TOLKAČEVA 2015]. Natalia Fedorova, in rather metaphorical terms, refers to media poetry as the 
translation of literature to the present time, as creation of literature using all existing technology [FEDOROVA 2018]. At the same time, Fedorova emphasizes the principle of play in works combining artistic word and modern technology. An important role in this line of Russian digital creation is played by the tradition of Russian cosmism, its spiritual, philosophical-religious form represented by Nikolai Fedorov in the 19th century, and its scientific form represented by the work of Konstantin Tsiolkovsky in the 2 oth century.

The second distinctive line on the current Russian experimental scene is represented by the authors associated with the St. Petersburg [Translit] journal. Digital technology plays a very important role in their work, however, calling it media poetry would be incorrect. Neither do they use the Internet simply to disseminate a literary experiment; their works utilize new technology while exploring it and reflecting its influence on writing and reading. They do not perceive it as a tool or a means of producing and disseminating texts, but rather as a phenomenon which redefines contemporary literary discourse and simultaneously can help to interpret it. Both in their art projects and theoretical texts, these authors examine the changing forms of writing and reading in the post-digital context. Another distinctive feature of this creative circle is their activism. The authors of A History of Russian Literature refer to them as a group in whose work "borders between theory and art practice are porous, as between writing and activism, many of the members may be best described as post-theorists" [KAHN, LIPOVETSKY, REYFMAN, SANDLER 2018, 563]. Furthermore, [Translit] authors are also referred to as cultural opponents of the mainstream: "As he (Dubin) notes, limited readership and division into groups and sub-groups are not the defining feature of post-underground literature. What matters more is the potential for a political position: Everything experimental in culture and everything repressed from public life has gained an induced political significance" [KAHN, LIPOVETSKY, REYFMAN, SANDLER 2018, 563]. This tendency has been systematically manifesting itself over a long period in the work of Pavel Arseniev, the editor-in-chief of the journal, who in his theoretical texts and art projects examines the materiality and performance of writing, and formulates original theses about the pragmatics of the literary situation. Arseniev was also one of the three core members of the Laboratory of Poetry Actionism (Лаборатория поэтического акционизма) group, a working community of poets, artists and philosophers who seek to overcome the alienation of everyday life by filling the urban space with poetry. It was within this group that Arseniev formulated the following objective: "some poems are not written in order to exist on paper, but need a different media environment. We try to create this environment for them, be it walls of buildings or virtual interface" [ARSEN'JEV 2013].

A common method of their work is the method of appropriation, Arseniev uses the term "ready written," which is also the title of one of his poetic cycles. Significantly, 
the Laboratory members re-interpret and present in a new context poetry texts of the Russian avant-garde (Vladimir Mayakovsky, Daniil Kharms), Moscow conceptualism (Vsevolod Nekrasov), but also non-poetic texts, fully in accordance with Arseniev's conviction that creation of new texts needs to be replaced by searching for new text strategies. Their projects often appear in several media environments, a text located in the urban space can later become a part of a gallery or web installation. In various projects, $P$. Arseniev explored the influence of texts that are brought into the urban space from poetry collections, from technical notifications of Facebook, and from contemporary ideological discourse. The [Translit] authors also experiment on social networking sites. Nikita Sungatov initiated collective writing of a genre known as "popular Facebook poems." Arseniev organized an interactive performance called A Post of Trust, in which participants shared their Facebook accounts. In this performance, Arseniev emphasizes a theme that has long been permeating his work: "desubjectivization of writing," i.e. "a strategic violation of authorship" [ARSEN'JEV 2015].

The [Translit] group also developed a project that evolved over time (2014-2017) and posed original questions about the transformations of authorship, the interconnection between man and technology, modern poetics, and the role of technology in creative work. This project also confirms the abovementioned statement that in the case of these authors, "the borders between theory and art practice are porous, as between writing and activism" [KAHN, LIPOVETSKY, REYFMAN, SANDLER 2018, 563]. In 2017, Pavel Arseniev nominated the poet Dora Vey for the Arkadii Dragomoshchenko literary award. In his nomination he stated: "Dora Vey is a poetry machine that uses the technology of spamdexing, based on Markov chain algorithms (doorway). The author's poetry was first introduced by Mikhail Kurtov in [Translit] \# 9-The Question of Technique. Dora Vey's poetry book is about to be published in the *kraft series. Dora lives and works in St. Petersburg" [ARSENJJEV 2017]. The following detailed explanation of the nomination is then used by Arseniev to join the debate about the character of contemporary young Russian poetry. The Arkadii Dragomoshchenko prize, awarded since 2014, is intended for poets under 27 years of age. The award is supposed to reveal current tendencies in poetry that respond to challenges of this age and facilitate a new way of understanding the "poetic." It should lead to an appropriate recognition of new directions and possibilities of writing, and to the encouragement of a discussion regarding the authors of the young generation. In the letter justifying the nomination, Arseniev openly argues against conservative literary criticism. He focuses primarily on the criticisms addressed to some young [Translit] poets, whose texts allegedly resemble the results of machine translation, "lack soul", and give the impression of "digitized" texts. Arseniev expresses ironic agreement with the statement that the discussion about the boundaries between human and artificial intelligence 
in contemporary poetry is topical. In the nomination, he quotes a study by Mikhail Kurtov titled Дорвеи: Жизнь и творчество (Doorways: Life and Work) published in the 9th issue of [Translit], in which the author analysed in detail the poetics of the doorway web pages, based on which the poet-algorithm Dora Vey got her name. The seemingly neutral wording of the nomination annotation "Dora Vey lives and works in St. Petersburg," is actually a reference to Kurtov's Doorways: Life and Work article [KURTOV 2014, 79-87] and suggests to the privy [Translit] reader and supporter that the nomination is part of a broader context. Kurtov's anthropologizing "Life and Work," which hints at the tone of a dictionary entry or a conventional article about a well-known writer, is given a specific location by Arseniev-"in St. Petersburg," which is indisputably absurd in the case of an algorithm. On the contrary, such localization can draw attention to the impossibility to localize "Dora" in the anthropological sense, and therefore to the contradiction and question of the possibilities of understanding the non-human that people have created and with which they are now entering a poetic dialogue.

In his 2014 study, Kurtov explains that "doorways are texts automatically generated from random-texts and key words, designed exclusively to be read by search-engine robots. Ordinary users do not see them: when they click on the doorway in the search results, they are automatically directed to a new page, where they will be offered an appropriate product or service. [...] Unlike email spam, which is still addressed to human beings, doorways are agents of pure machine communication." [KURTOV 2014, 80] Reading doorway texts, one seems to look into another world, into a discourse which is not supposed to be read by a person, and which is actually created to manipulate people, to influence their navigation on the Internet. If these pages open up, either as a result of an accidental failure of technology or as a result of an intentional and informed search, one can get into the doorway texts, become captivated by the surreal poetics of non-human discourse, and give in to the dizziness caused by questions which can be posed by such texts. According to some data, the volume of these texts, intended solely for machine communication, exceeds the volume of "human" texts, i.e. web pages intended for people (“сайт для людей”/“website for people" is a slang term used by Russian webmasters). In his justification of nominating Dora Vey for the literary award, P. Arseniev categorizes "her" texts as spam-poetry (mail spam), flarf, Google poetry, but claims that the doorway texts significantly exceed these genres by aesthetic quality. He even finds correspondence between the poetics of the doorway and the poetic experiments of Arkadii Dragomoshchenko himself in the extensive use of parataxis. According to Arseniev, the algorithms are much better, more inventive than people, and their texts are characterized by "surrealism of images and nonsense out of control" [ARSEN'JEV 2017]. Arseniev follows Kurtov's 2014 study and complements it with radical questions regarding authorship in the post-digital 
era. Finally, he raises a rhetorical question as to whether these days we really have to assume that only a person (mostly under the age of 27) can be considered the author of poetic texts.

In 2017, Kurtov published a printed anthology of doorway poetry called Лaкmam Гагарина. Избранное собрание поискового спама (Gagarin's Lactate. Selected Works by Search engine Spam). When presenting the book, Kurtov spoke about the doorway as a combination of ready-made texts and poetry generators. He identifies the doorway as imagination outlaws, self-liberating generators, which offer new meanings every day through new word strings, explore the valency of words, and with their experiments broaden our ideas of what is possible. The name of the collection is obviously a product of doorway poetics. Kurtov explains his choice of words by playing with the theme of cosmos, the Soviet era, the 1960s, which he considers a period of machine naivety and innocence. The reference to the 1960 s also refers to the development of computers, the expectations associated with them in contrast to today's state of sobering [KURTOV 2018]. In his introduction to the poetry book, M. Kurtov describes doorway texts as unrestrained electronic literature that grows literally from waste [KURTOV 2017, 9]. Incidentally, this is one of the rare cases of using the term electronic literature in the Russian environment.

Although it is possible to place the works of [Translit] in the broad context of digital literature, they differ from the representatives of Russian media poetry in that they mostly use the method of appropriation, work with found texts in accordance with the ready written approach, diagnose them and put them into new contexts. Their work raises questions regarding the dialogue between the contemporary author and the reader, the changing or even disappearing boundaries between them, the dialogue between the human and non-human principles that meet in the creative process, and the related questions about creative inspiration and imagination. Their performances, installations and text objects raise questions about the extent to which machines created by people reflect (or adopt) human creative gesture and how they change the author's situation. Their work in this sense therefore fits in the context of Russian post-humanism. At the same time, it proves that the radical, non-sentimental, rational, non-prejudicial conception of the author's gesture, which fully utilizes the post-digital situation and the transmedia approach, leads to their artistic expression having the inseparable connection between researching materiality and performance of contemporary literature, and civil activism. 


\section{References:}

ARSEN'JEV, P. (2013): Interv'ju «Moskovskim novostjam». 3 marta 2013. <https:// poetryactionism.wordpress.com/page/2/>. [online]. [cit. 10. 12. 2019].

ARSEN'JEV, P. (2015): Post doverija. <http://arsenev.trans-lit.info/?p=286\&lang=ru_ RU>. [online]. [cit. 10. 12. 2019].

ARSEN'JEV, P. (2017): Dora Vej (Sankt-Peterburg). Premija Arkadija Dragomoščenko. $<$ http://atd-premia.ru/2017/o9/21/dora-vey/>. [online]. [cit. 11. 1. 2020].

FEDOROVA, N. (2018): Art.Is.Natalia. <http://artisyou.ru/ru>. [online]. [cit. 17. 10. 2019].

KAHN, A., LIPOVETSKY, M., REYFMAN, I., SANDLER, S. (2018): A History of Russian Literature. Oxford.

KURTOV, M. (2014): Dorvei. Žizn' i tvorčestvo. [Translit] Vopros o technike, 2014, № 9, s. $79-87$.

KURTOV, M. (2017): Ot sostovitelja. In: Laktat Gagarina. Izbrannoje sobranije poiskovogo spama. Sankt-Peterburg.

KURTOV, M. (2018): Dora Vej. Soprotivlenije poèzii. <https://vimeo.com/250632294>. [online]. [cit. 1. 10. 2019].

Laktat Gagarina. Izbrannoje sobranije poiskovogo spama. (2017). Sankt-Peterburg.

LEJBOV, R. (2010): Sovremennaja literatura i Internet. POLIT.RU 18 fevral' 2010. < https:// polit.ru/article/2010/02/18/leibov/>. [online]. [cit. 10. 12. 2019].

Odinnaodin. Festival' mediapoèzii. (2018.) <https://www.101.ru.com/2017?fbclid=IwAR 1Q6tt_dgWZdGf5HzHe-PyaWXA9h1X1GsHk9kSBg9fXJ6Q855Xdg1qjKLw>. [online]. [cit. 10. 11. 2020].

TOLKAČEVA, A. (2015): Mediapoèzija - èto... Arterritory. Baltic, Russian and Scandinavian Art Territory. 8 ijun' 2015. <http://www.arterritory.com/ru/teksti/statji/4748mediapojezija_jeto...>. [online]. [cit. 19. 9. 2019].

\section{About the author}

Jana Kostincová, University of Hradec Králové, Faculty of Education, Department of Russian Language and Literature, Hradec Králové, Czech Republic, jana.kostincova@uhk.cz 
